\title{
Enhanced Oil Recovery: Projects Planning Strategy in Angolan Oilfields
}

\author{
Geraldo Ramos ${ }^{\mathrm{a}}$ and Kyari Yates ${ }^{\mathrm{b}}$
}

\begin{abstract}
${ }^{a}$ Petrotechnic and Engineering School, Sonangol Academy, Avenida Luanda Sul, Rua Lateral S10, Talatona, Luanda, Angola. ${ }^{a}$ Department of Geoscience (DGC), Instituto Superior Politecnico de Tecnologias e Ciências (ISPTEC), Avenida Luanda Sul, Rua Lateral S10, Talatona, Luanda, Angola

${ }^{\mathrm{b}}$ School of Pharmacy and Life Sciences, Robert Gordon University, Aberdeen, UK
\end{abstract}

\section{ARTICLE INFO}

\section{Keywords:}

Enhanced Oil

Recovery (EOR)

mature fields,

reservoir screening

\begin{abstract}
Hydrocarbon exploration in Angola commenced in 1910 with its first oil recovered in 1955. Most of the Angolan oilfields are mature or maturing and some are or may be abandoned due to unprofitable recovery limit beyond the conventional type of oil production. The oil recovery is mainly by primary and secondary recovery methods. Apart from the issue of maturity, there is increasing energy demand due to population growth and difficulties in discovering and developing new fields as alternatives to the current oilfields. For incremental and sustained production rate of these fields and in addition to instability of oil prices and concerns about future oil supply, Angola has started to work towards developing affordable and efficient technologies capable of recovering residual oil in reservoirs as well as extend the life of many current fields which can be achieved through the implementation of enhanced oil recovery (EOR). Therefore, this paper discusses the EOR planning strategy from project selection, project implementation and optimization, and field abandonment. It further highlights the mutual benefits that may be derived from a cross-collaboration between the government and other stakeholders in Angola.
\end{abstract}

\section{Introduction}

The maturation or decreasing oil production in recent years and the challenge of recovering additional oil from mature fields in Angola has necessitated the need for the development of advanced techniques to recover oil beyond the primary and secondary mechanisms. The capillary pressure, wettability, interfacial forces, high oil viscosity, high water cut, heterogeneity of the reservoir and shear viscosity forces are some of the variables that could be attributed to the ability or inability of oil to move towards the wellbore.

The recovery process is more complex when dealing with offshore oilfields where the location and spacing of the wells and reservoir depth are higher compared to onshore oilfields. Hence, enhanced oil recovery (EOR) implementation can extract up to over half of the reservoir's original oil content ${ }^{[1,2,3,4]}$ and extend the productive life of oilfields, particularly in fields where the less risky and more conventional methods have been exhausted [5]. However, the selection, testing, and implementation of this technique involves several steps and challenges mainly for new mature fields (new Brownfields).

The EOR study requires extensive data from the wells, reservoirs or fields under investigation, knowledge of the geological structure and lithology of the fields and complex experimental studies of liquid-fluid or rock-fluid interactions as well as the formulation of fluids ${ }^{[6]}$. Besides the limited subsurface understanding, there are some other barriers to implementing EOR projects such as the supply of secure, low-cost injectants; the challenge of implementing the EOR retrospectively on a brownfield site and concerns over project economics ${ }^{[7]}$.

Before EOR implementation, screening investigation is required to decide whether an EOR technique is suitable or not for a specific oilfield ${ }^{[8,9,10]}$. Hence in Angola, a National EOR Work Team (ANEWT) within the National Agency for Oil, Gas and Biofuels (ANPG) must be set up to co-ordinate the Angolan Oil industry and government attempts to design and develop the EOR program together with operators and service companies to ensure that overall hydrocarbons recovery is maximized. Apart from this, the ANEWT should be responsible for: (1) elaboration of a strategic and comprehensive plan on the implementation of EOR in Angola; (2) work toward the legislative decree that guides the inclusion of EOR in current and future production sharing contracts; (3) seek for tax and contractual incentives in order to enable and reduce the economic risk of the EOR implementation; (4) create a national structure or centre for studies on EOR and $\mathrm{CO}_{2}$ storage; (5) conduct a national study to assess the potential for application of EOR in Angola; (6) boost technology and culture in the EOR projects through innovation; (7) greater dissemination and communication with operators and service providers as well as small and medium companies; (8) elaboration of the procedure with a commitment of the managers involved in the program.

The success of EOR projects is achieved once the operators focus their efforts on reviewing all ways of maximizing recovery from their existing fields. This is a medium- and long-term project with several steps in which the three main phases are: (1) systematically screen the EOR potential of Angolan oilfield; (2) engage industry and look for synergies and collaborative opportunities to progress EOR understanding; (3) where possible, initiate EOR projects with operators [7], service companies as well as the small and medium companies.

\section{EOR Concepts and Classification}

Hydrocarbon recovery is at the heart of oil production from underground reservoirs [11] and occurs through three main processes (Fig. 1): primary oil recovery (natural flow and artificial lift), secondary oil recovery (water flooding and pressure maintenance) and enhanced oil recovery (EOR) also known as tertiary recovery ${ }^{[11,12,13,14]}$.

During the primary and secondary recovery stages, mobile oil is easily extracted whereas EOR is adopted properly to extract immobile oil trapped under capillary and viscous forces ${ }^{[6,11]}$. Much work on research and field implementation has been done to improve oil recovery from 
depleted oil reservoirs using non-conventional oil recovery techniques. Hite et al. ${ }^{[13]}$ refers to enhance oil recovery as processes that recover oil not produced by secondary recovery. This definition is quite general since there are several techniques like IOR (improved oil recovery) that could be applied to recover additional oil beyond secondary recovery. There is considerable confusion in the usage of the terms EOR and IOR (Improved Oil Recovery). The term IOR (Improved Oil Recovery) refers to any practice to increase oil recoveries, such as improved reservoir characterization and management (automation, smart wells), advanced drilling techniques and other production enhancement methods. This includes EOR processes, practice to increase sweep efficiency such as additional vertical wells (infill drilling) or complex well designs (deviated or inclined wells; horizontal or lateral wells, multilateral wells, multilateral wells), reservoir stimulation (fracture, acid), artificial elevation (beam pumps, electrical submersible pumps and gas elevation), secondary recovery methods (water and gas injection) [15,16,17].

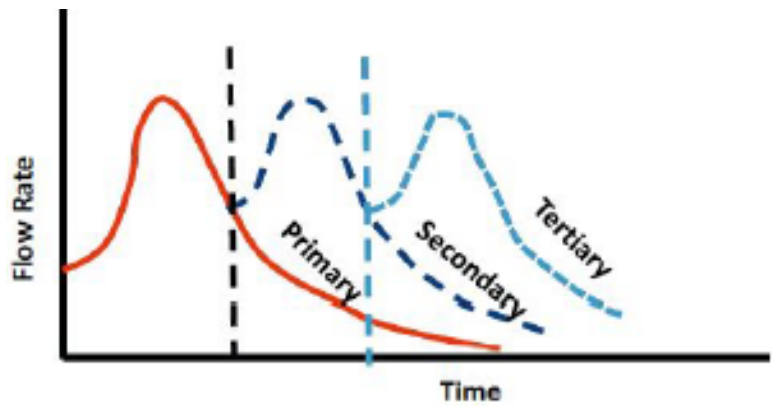

Figure 1: Oil recovery categories. Adapted Ahmed and Meehan ${ }^{[18]}$

However, Lake [19] defines EOR as an oil recovery process by injecting materials not normally present in the reservoir. This definition excludes water and gas injection which are used to maintain reservoir pressure as well as miscible or immiscible gas processes which are also EOR processes. Also, EOR can be viewed as an oil recovery by injection of gases or chemicals and/or thermal energy into the reservoir. It is not restricted to a particular phase in the producing life of the reservoir ${ }^{[20]}$. This definition applies to EOR processes but is not restricted as only tertiary recovery since thermal processes can be implemented at an early stage of production.

For this investigation, we define enhanced oil recovery (EOR) as a set of production technologies that involve the injection of energy or fluids to improve oil recovery at any stage of production, whether primary, secondary, or tertiary, in order to increase the total recovery above what is possible through traditional methods ${ }^{[21] .}$

\subsection{Enhanced Oil Recovery Classification}

EOR methods are classified based on different techniques as well as the applications and physical processes associated with the different techniques. Hence, enhanced oil recovery methods can be divided into four techniques (Fig. 2): thermal, chemical, gas miscible and immiscible and others. Based on physical processes associated with different techniques and methods, EOR can be classified into two categories linked to microscopic and macroscopic sweep efficiency with some acting in both microscopic and macroscopic sweep efficiencies as illustrated in Fig. 3.

The potential of thermal processes exists for heavy crude oils which cannot be produced at the original reservoir pressure and temperature. The oil viscosity can be dramatically decreased by raising the reservoir temperature and enabling the oil to flow more readily towards the producing well. The heat for the thermal process is provided by steam or hot water injection, or by burning some of the oil in place (in situ combustion). However, for remote areas where the cost of importing chemicals could be prohibitive, the possibility of in situ combustion has been proposed [22]. The cost of heating in thermal methods is tied to the cost of oil so that when the price of oil decreases, the cost of the heating also decreases, which is an advantage of the thermal methods.

The chemical flooding method is used to lower the viscosity or the interfacial tension (IFT) of oil, or to increase the swept volume of the reservoir. Chemical flooding involves the use of polymer, surfactant, alkali or combination of these to aid the recovery process. The process' economics need to be carefully scrutinized independent of the oil price due to the associated increase in costs of this process ${ }^{[22]}$.

In miscible flooding, fluid is either directly miscible with the oil in the reservoir or extracts components from the oil which forms a bank of liquid miscible with both the reservoir and the injected gas-carbon dioxide, hydrocarbon gases, liquefied petroleum gas (LPG) or nitrogen (for deep, high-pressure reservoirs). For better recovery, miscible floods are often alternated with water floods to improve the sweep efficiency of the process, as the miscible fluid is generally less viscous than the oil and tends to" finger" through the oil, giving a sweeping efficiency much less than 100\%. Immiscible flooding with carbon dioxide is also used, as even without miscibility the carbon dioxide swells the oil and reduces its viscosity [22].

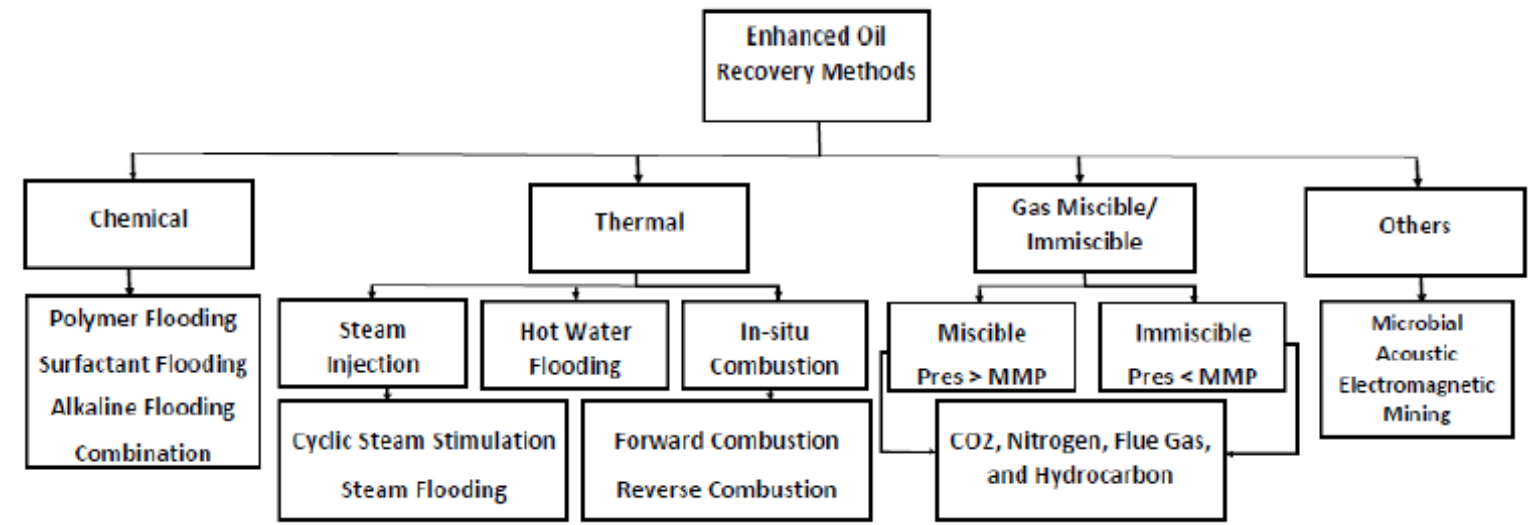

Figure 2: Classification of enhanced oil recovery methods. Pres is the fluid injection pressure in reservoir and MMP the minimum miscible pressure. Adapted from Al-Anazi ${ }^{[2]}$, Hite et al. ${ }^{[11]}$, Kokal and Al-Kaabi ${ }^{[13]}$

\subsection{Residual Oil Recovery}

The main purpose of EOR methods is the recovery of immobile oil (residual oil) left beyond the conventional oil recovery. This process contributes to increasing recovery factor. The recovery factor equation is summarized by four variables as shown in Equation 1: (1) pore-scale displacement (PSD) the ability of recovery process to displace oil or gas, (2) sweep efficiency (SE) - movement of mobile oil and gas to wells, (3) drainage (D) - connection of wells to oil and gas and (4) time (T) - physical and commercial constraints affecting end of field life ${ }^{[7]}$.

$$
R F=P S D \times S E \times D \times T
$$

The first two variables are the focus of EOR whereas the last two are the focus of IOR. The pore-scale displacement can be improved by low salinity water flooding, miscible gas injection and surfactants etc. Sweep efficiency can be improved by incorporating chemical flooding such as polymers for 
water floods or foam for gas injection. Drainage and Time (cut offs) are influenced through established IOR techniques such as infill wells and workover. These four variables together determine the overall recovery factor for a field. Increasing recovery factor requires one of these factors to be increased to as close to 1 as possible. Hence, maximizing recovery factor in a field requires optimization of all four variables in Equation 1.

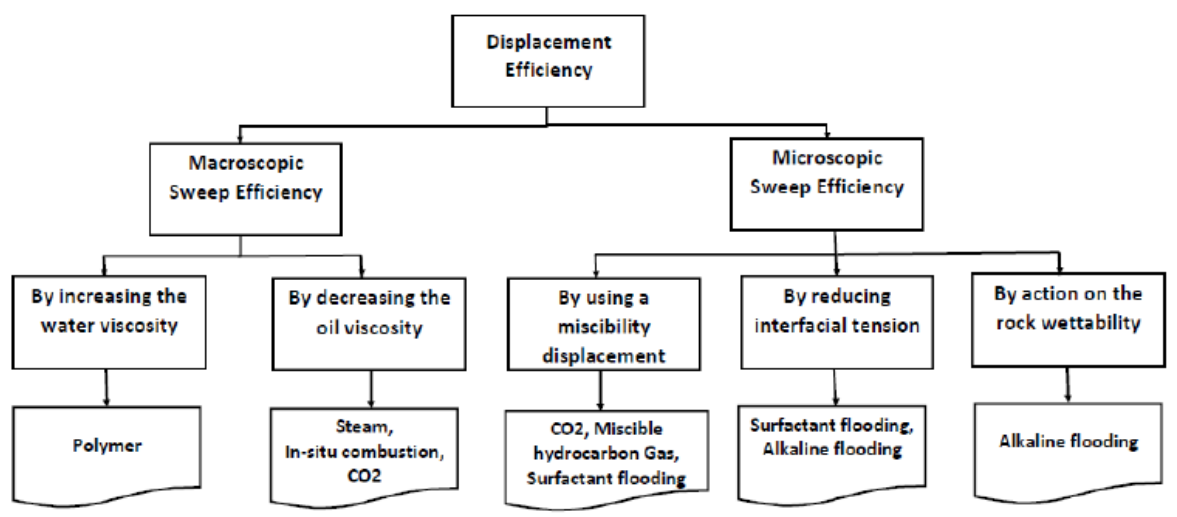

Figure 3: Macroscopic and microscopic effect of sweep efficiency of EOR.

Muggeridge et al. ${ }^{[25]}$, Smalley et al. ${ }^{[26]}$ in their work reported the factors affecting the microscopic and macroscopic displacement efficiency. According to Muggeridge et al. ${ }^{[25]}$, EOR methods focus on increasing the microscopic and macroscopic sweep efficiency. The microscopic displacement efficiency is affected by capillary number ${ }^{[25,27,28]}$ and relative permeability characteristics of the rock ${ }^{[25,29]}$ in which both are also affected by wetting behaviour of the rock in which the oil is found ${ }^{[25]}$. Hence, according to Muggeridge et al. ${ }^{[25]}$, reducing capillary effects, by reducing the oil-water IFT, and modifying the rock wettability to optimum mixed wettability state are the main requirements for increasing the microscopic displacement efficiency.
The factors influencing macroscopic sweep efficiency were also discussed in the work presented by Muggeridge et al. ${ }^{[25]}$. According to their investigation, the macroscopic sweep efficiency is mainly affected by geological heterogeneity in the reservoir and gravitational segregation. Improving the macroscopic sweep efficiency depends on minimizing the impact of geological heterogeneity which is achieved by a mixture of viscosity modification of the displacing fluid or diverting injected fluid from the higher into the lower permeability zones still containing displaced fluid ${ }^{[25]}$, as well as the gravitational segregation for gas floods ${ }^{[30]}$. The summary of thermal, chemical, and miscible gas EOR are described in Tables 1, 2, and 3 , respectively. These include the basic principles, mechanisms, limitations, problems, typical recovery, and typical agent utilization.

Table 1: Thermal EOR production mechanisms, limitations, problems ${ }^{[2,14,18,19,31,32,33]}$

\begin{tabular}{|c|c|c|c|c|c|c|}
\hline EOR Process & Basic Principals & Mechanisms & Limitations & Problems & $\begin{array}{l}\text { Typical } \\
\text { Recovery } \\
(\%)\end{array}$ & $\begin{array}{l}\text { Typical } \\
\text { agent } \\
\text { utilization }\end{array}$ \\
\hline Steam & $\begin{array}{l}\text { Improvement of } \\
\text { sweep and } \\
\text { displacement } \\
\text { efficiencies }\end{array}$ & 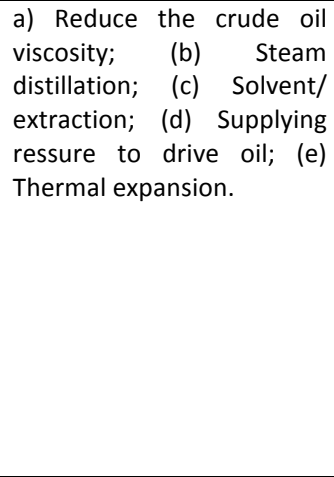 & $\begin{array}{l}\text { (a) requires high oil } \\
\text { saturation; (b) } \\
\text { Pay zone >20 ft to } \\
\text { minimise heat losses; } \\
\text { (c) Applicable to viscous } \\
\text { oils; (d) Applicable to } \\
\text { high permeability } \\
\text { sandstones or } \\
\text { unconsolidated sands; } \\
\text { (e) Preferable to } \\
\text { shallow reservoir due } \\
\text { to the excessive heat } \\
\text { loss; (f) Undesirable for } \\
\text { water and gas caps. }\end{array}$ & 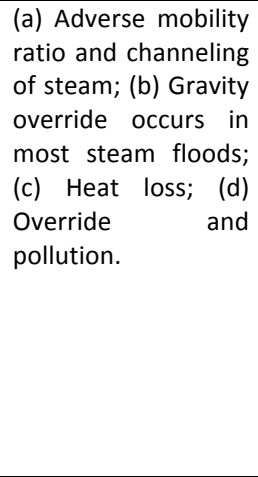 & $50-60$ & $\begin{array}{l}0.5 \text { bbl oil } \\
\text { consumed } \\
\text { per bbl oil } \\
\text { produced }\end{array}$ \\
\hline $\begin{array}{l}\text { In-situ } \\
\text { combustion }\end{array}$ & $\begin{array}{l}\text { Improvement of } \\
\text { sweep and } \\
\text { displacement } \\
\text { efficiencies }\end{array}$ & $\begin{array}{l}\text { (a) Decrease viscosity by } \\
\text { heat conduction and } \\
\text { convection; (b) Product of } \\
\text { steam distillation and } \\
\text { thermal cracking mix with } \\
\text { and upgrade the crude oil; } \\
\text { (c) The coke produced from } \\
\text { the heavy ends of the } \\
\text { crude oil is burnt; (d) The } \\
\text { injected air provides } \\
\text { pressure to the reservoir; } \\
\text { (e) Reduces oil saturation; } \\
\text { (f) Vaporizing some liquid } \\
\text { and generating steam. }\end{array}$ & $\begin{array}{l}\text { (a) If sufficient coke is } \\
\text { not deposited from the } \\
\text { oil being burnt, the } \\
\text { combustion process will } \\
\text { not be sustained; (b) If } \\
\text { excessive coke is } \\
\text { deposited, the rate of } \\
\text { advance of the } \\
\text { combustion will be } \\
\text { slow, and the quality of } \\
\text { the air required to } \\
\text { sustain combustion will } \\
\text { be high; (c) Oil } \\
\text { saturation and porosity } \\
\text { must be high to } \\
\text { minimise heat loss to } \\
\text { rock; (d) Tends to } \\
\text { sweep through the } \\
\text { upper part of the } \\
\text { reservoir thus the } \\
\text { sweep efficiency is poor } \\
\text { in thick formation. }\end{array}$ & $\begin{array}{l}\text { (a) Adverse mobility } \\
\text { ratio; (b) Difficult to } \\
\text { control combustion, } \\
\text { and requires large } \\
\text { capital investments; } \\
\text { (c) Produce flue } \\
\text { gases that can cause } \\
\text { environmental } \\
\text { problems; (d) Severe } \\
\text { corrosion caused by } \\
\text { low pH hot water; } \\
\text { (e) serious oil-water } \\
\text { emulsions; (f) } \\
\text { Increased sand } \\
\text { production, } \\
\text { deposition of carbon } \\
\text { or wax, and pipe } \\
\text { failures as a result of } \\
\text { the very high } \\
\text { temperatures; (g) } \\
\text { Excessive heat loss. }\end{array}$ & $10-15$ & $\begin{array}{l}10 \text { Mscf air } \\
\text { per bbl oil } \\
\text { produced. }\end{array}$ \\
\hline
\end{tabular}




\begin{tabular}{|c|c|c|c|c|c|c|}
\hline EOR Process & Basic Principals & Mechanisms & Limitations & Problems & $\begin{array}{l}\text { Typical } \\
\text { Recovery } \\
\text { (\%) }\end{array}$ & $\begin{array}{l}\text { Typical } \\
\text { agent } \\
\text { utilization }\end{array}$ \\
\hline Surfactant & $\begin{array}{l}\text { Improvement } \\
\text { of sweep and } \\
\text { displacement } \\
\text { efficiencies }\end{array}$ & $\begin{array}{l}\text { (a) Lowering } \\
\text { interfacial tension; (b) } \\
\text { Solubilisation of oil; } \\
\text { (c) Emulsification of } \\
\text { oil and water; (d) } \\
\text { Mobility } \\
\text { enhancement. }\end{array}$ & $\begin{array}{l}\text { (a) Areal sweep > } \\
50 \% \text { on a waterflooding } \\
\text { is desired; } \quad \text { (b) } \\
\text { Homogenous formation } \\
\text { are preferred; } \quad \text { (c) High } \\
\text { amounts of anhydride, } \\
\text { Sypsum, or clays are } \\
\text { undesirable; } \\
\text { Chloride's concentration } \\
\text { in formation waters < } \\
20,000 \text { ppm; (e) and } \\
\text { divalent ions (Ca++ and } \\
\text { Mg++)<500 ppm. }\end{array}$ & $\begin{array}{l}\text { (a) Large adsorption of } \\
\text { surfactants; (b) Possibility } \\
\text { of chromatographic } \\
\text { separation of chemicals; } \\
\text { (c) Interaction between } \\
\text { surfactant and polymer; } \\
\text { (d) Degradation of } \\
\text { chemicals mixture at high } \\
\text { temperatures; (f) } \\
\text { Injectivity and stability at } \\
\text { high salinity; (g) Chemical } \\
\text { availability and retention. }\end{array}$ & 15 & $\begin{array}{l}15-25 \mathrm{lb} \\
\text { surfactant } \\
\text { per bbl oil } \\
\text { produced }\end{array}$ \\
\hline Polymer & $\begin{array}{l}\text { Improvement } \\
\text { of sweep and } \\
\text { displacement } \\
\text { efficiencies }\end{array}$ & 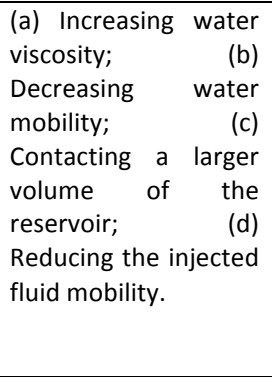 & 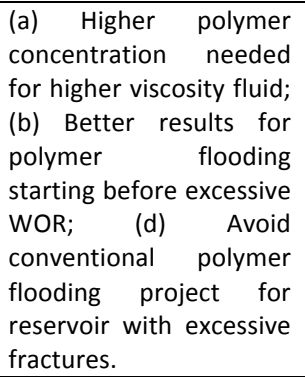 & $\begin{array}{l}\text { (a) Lose viscosity due to } \\
\text { shear degradation or } \\
\text { increases in salinity and } \\
\text { divalent ions; (b) Limited } \\
\text { to reservoir } \\
\text { temperatures < } 93 \mathrm{C} \text {; (c) } \\
\text { Issues with injectivity, } \\
\text { stability and high salinity. }\end{array}$ & $5-12$ & $\begin{array}{l}0.3-0.5 \mathrm{lb} \\
\text { polymer per } \\
\text { bbl oil } \\
\text { produced }\end{array}$ \\
\hline Alkaline & $\begin{array}{l}\text { Improvement } \\
\text { of sweep and } \\
\text { displacement } \\
\text { efficiencies }\end{array}$ & \begin{tabular}{lr}
\multicolumn{1}{c}{$(\mathrm{a})$} & Mobility \\
control; (b) Emulsion \\
and & wettability \\
alteration; & (c) \\
Lowering & interfacial \\
tension. &
\end{tabular} & $\begin{array}{l}\text { (a) Applicable to oil } \\
\text { ranging between } 13 \text { to } \\
35 \quad \text { API; (b) Not } \\
\text { preferable in carbonate } \\
\text { reservoirs because of } \\
\text { presence of anhydrite or } \\
\text { gypsum which consumes } \\
\text { a large amount of } \\
\text { alkaline chemicals. }\end{array}$ & $\begin{array}{l}\text { (a) Scale formation in } \\
\text { producing well; (b) } \\
\text { Injectivity, stability and } \\
\text { high salinity; (c) Chemical } \\
\text { availability and retention. }\end{array}$ & 5 & $\begin{array}{l}35-45 \mathrm{lb} \\
\text { chemical } \\
\text { per bbl oil } \\
\text { produced }\end{array}$ \\
\hline
\end{tabular}

Table 3: Miscible gas EOR production mechanisms, limitations, problems ${ }^{[2,14,18,19,31,32,33]}$

\begin{tabular}{|c|c|c|c|c|c|c|}
\hline EOR Process & $\begin{array}{l}\text { Basic } \\
\text { Principals }\end{array}$ & Mechanisms & Limitations & Problems & $\begin{array}{l}\text { Typical } \\
\text { Recovery (\%) }\end{array}$ & $\begin{array}{l}\text { Typical } \\
\text { agent }\end{array}$ \\
\hline $\begin{array}{c}\mathrm{N}_{2} \text { and Flue } \\
\text { Gas }\end{array}$ & $\begin{array}{l}\text { Improvement } \\
\text { of } \\
\text { displacement } \\
\text { efficiency. }\end{array}$ & $\begin{array}{l}\text { (a) Vaporising the } \\
\text { lighter components } \\
\text { of the crude oil; (b) } \\
\text { Providing a gas drive } \\
\text { to the reservoir; (c) } \\
\text { Increase injectivity; } \\
\text { (d) Reduces } \\
\text { viscosity. }\end{array}$ & $\begin{array}{l}\text { a) Miscibility with light oils at } \\
\text { high pressure; b) Applicable } \\
\text { in deep reservoirs; c) dipping } \\
\text { reservoir is desired to permit } \\
\text { gravity stabilization of the } \\
\text { displacement that normally } \\
\text { has an unfavourable mobility } \\
\text { ratio. }\end{array}$ & $\begin{array}{l}\text { (a) Poor vertical and } \\
\text { horizontal sweep } \\
\text { efficiencies as result of } \\
\text { viscous fingering; } \quad \text { (b) } \\
\text { Corrosion can cause } \\
\text { problems in flue gas. }\end{array}$ & $5-15$ & $\begin{array}{l}10 \text { Mscf } \\
\text { solvent per } \\
\text { bbl oil } \\
\text { produced }\end{array}$ \\
\hline $\mathrm{CO}_{2}$ & $\begin{array}{l}\text { Improvement } \\
\text { of } \\
\text { displacement } \\
\text { efficiency. }\end{array}$ & $\begin{array}{l}\text { (a) Generate } \\
\text { miscibility between } \\
\text { oil and } \mathrm{CO}_{2} ;(\mathrm{b}) \\
\text { Swelling of oil; (c) } \\
\text { Reduces viscosity of } \\
\text { the oil; (d) Lowering } \\
\text { the interfacial } \\
\text { tension between } \\
\text { the oil and the } \mathrm{CO}_{2} \text {. }\end{array}$ & $\begin{array}{l}\text { (a) Poor viscosity control due } \\
\text { to low viscosity of } \mathrm{CO}_{2} \text {; (b) } \\
\text { Availability of } \mathrm{CO}_{2}\end{array}$ & $\begin{array}{l}\text { (a) Early breakthrough of } \\
\mathrm{CO}_{2} \text {; (b) Corrosion in the } \\
\text { producing wells; } \text { (c) } \\
\text { Repressuring of } \mathrm{CO}_{2} \text { for } \\
\text { recycling; (d) } \mathrm{A} \text { high } \\
\text { requirement of } \mathrm{CO}_{2} \text { per } \\
\text { incremental barrel } \\
\text { produced; (e) Stability, } \\
\text { override and supply. }\end{array}$ & $5-15$ & $\begin{array}{l}10 \text { Mscf } \\
\text { solvent per } \\
\text { bbl oil } \\
\text { produced. }\end{array}$ \\
\hline $\begin{array}{l}\text { Hydrocarbon } \\
\text { Gas }\end{array}$ & $\begin{array}{l}\text { Improvement } \\
\text { of } \\
\text { displacement } \\
\text { efficiency. }\end{array}$ & $\begin{array}{l}\text { (a) Generates } \\
\text { miscibility in the } \\
\text { condensing and } \\
\text { vaporizing gas drive; } \\
\text { (b) Swelling of oil; (c) } \\
\text { Decreases the } \\
\text { viscosity of the oil. }\end{array}$ & $\begin{array}{l}\text { (a) The required pressure } \\
\text { range is about } 1,200 \text { psi for } \\
\text { the LPG process to } 3,000- \\
5,000 \text { psi for the high- } \\
\text { pressure gas drive; (b) The } \\
\text { desirable formation is } \\
\text { steeply dipping formation } \\
\text { that allow some gravity } \\
\text { stabilization of the } \\
\text { displacement that normally } \\
\text { has an unfavourable mobility } \\
\text { ratio. }\end{array}$ & 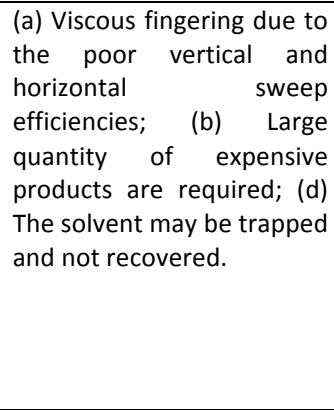 & $5-15$ & $\begin{array}{l}10 \text { Mscf } \\
\text { solvent per } \\
\text { bbl oil } \\
\text { produced }\end{array}$ \\
\hline
\end{tabular}


Reducing the IFT [18], the capillary number increases and the residual oil saturation decreases as illustrated in Fig. 4

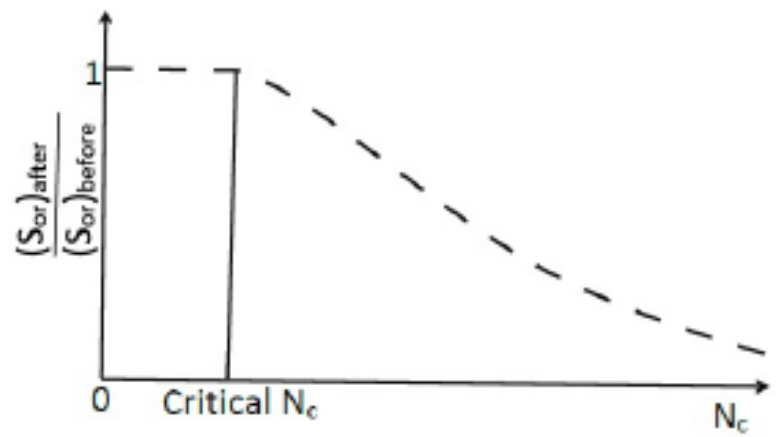

Figure 4: Effect of capillary number $(\mathrm{Nc})$ on residual oil saturation (Sor). Adapted from Ahmed and Meehan [18]
The value of residual oil saturation can get close to zero when IFT reaches the ultra-low values [34]. Hence, more oil can be produced. Mathematically, the capillary number is described as:

$$
N_{c a}=\frac{v \mu}{\sigma \operatorname{Cos} \theta}
$$

Where $v$ is the velocity, $\mu$ is fluid dynamic viscosity, $\sigma$ is the interfacial tension, and $\theta$ is the contact angle. $\theta$ is related to the wettability on specific surfaces [21]. Equation 2 reflect the ratio between two forces: the viscous drag of the fluid $(v \mu)$ over the interfacial contribution given by interfacial tension $(\sigma)$. If this number is small, fluid motion is impacted or dominated by capillary forces, while viscous forces dominate for $\mathrm{N}_{\mathrm{ca}}>1$ [21]. Figure 5 illustrates EOR target for different hydrocarbon. In general, the average worldwide hydrocarbon recoveries for primary recovery is in the range of 5 to $15 \%$ and secondary up to $1 / 3(\sim 33 \%)$ of the original oil in place.
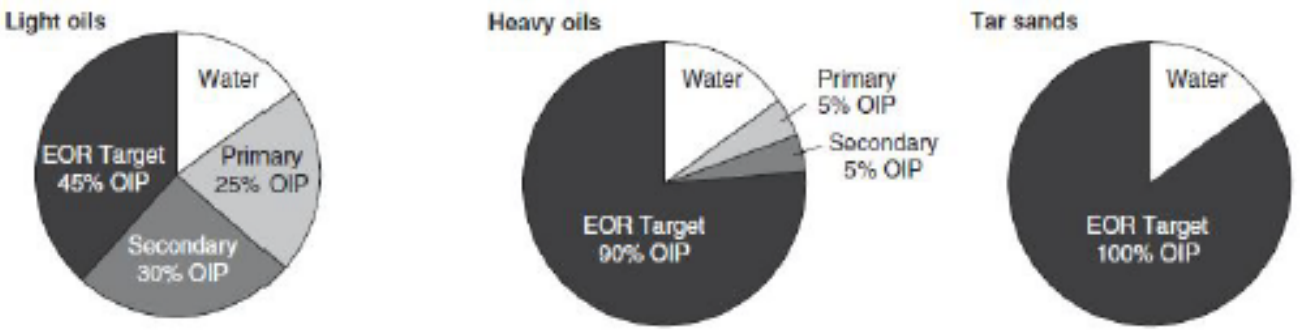

Figure 5: EOR target for different hydrocarbon. Assuming $\mathrm{S}_{\mathrm{oi}}=85 \% \mathrm{PV}$ and $\mathrm{S}_{\mathrm{w}}=15 \% \mathrm{PV}[35]$

\section{EOR opportunities and challenges}

Applying EOR techniques involve many opportunities and challenges from the design phase to the implementation and monitoring phase. These challenges can be technical, environmental, geographical, logistical, economic and political.

\subsection{EOR opportunities}

The implementation of EOR projects can impact on national oil production due to the potential to recover more than half of the hydrocarbons present in the reservoir as well as to extend the life cycle of the wells.

Besides, EOR implementation can generate other projects such as carbon dioxide $\left(\mathrm{CO}_{2}\right)$ sequestration and storage and deliver it to offshore or onshore fields. The sequestration of $\mathrm{CO}_{2}$ from power plants and industrial sources, in addition to being used to improve the recovery factor, also contributes to the reduction of greenhouse gas emissions. $\mathrm{CO}_{2}$ capture opportunities may not be economically viable or practical for an individual oil company [36], therefore a joint approach is recommended between oil industry companies and the government.

EOR application can also generate political opportunities requiring a close relationship with government entities (Ministry of Petroleum and Mineral Resources, National Petroleum and Natural Gas Agency), National Oil Companies (NOCs), International Oil Companies (IOCs), local and international service providers ${ }^{[36]}$. This relationship requires defining long and short-term objectives to leverage the implementation of EOR processes. These objectives should include agreements for sharing technical and economic risks, reviewing the design terms and lifetime of the project, as well as production sharing contracts. These agreements create opportunities for small, medium and big national and foreign companies from logistics and implementation, generating more jobs that can improve the social conditions of the local population and allowing the collection of more financial resources at the country level.

\subsection{EOR Challenges}

EOR challenges are most notable in offshore operations, particularly those in deep and ultra-deep waters. Drilling offshore wells is more expensive compared to onshore operations. The space between offshore wells is greater compared to onshore, negatively affecting the acquisition of data and the characterization of reservoirs, which contributes to the increase in the initial response time to reach production wells.

The infrastructures constraints require the resizing of the existing platforms to create more spaces and increase the capacity to add more weight to equipment related to EOR processes. These equipment's include those used for mixing and handling injectors, separating, treating and disposing of water, handling and compressing the gas. To reduce time and costs in offshore EOR operations we suggest from this paper that during the development phase, the platforms should be re-sized or upgraded with extra space and the ability to add more equipment that can be used during the EOR testing and implementing phases.

The availability of reservoir rock-fluid data from the fields under investigation and data from successful global EOR projects are also one of the challenges during an investigation and execution of EOR projects as well as the development of cheap and environmentally friendly techniques. Identifying suitable EOR techniques and their application in commingled wells in onshore fields is one other major challenge. Logistical issues related to the supply of equipment and injection fluids for offshore operations as well as the treatment of fluids produced during the implementation of EOR processes [36] constitutes a further challenge.

The economic and environmental challenges depend on the process to be implemented (thermal, gaseous and chemical). For thermal processes, the major challenges are the emission of greenhouse gases in which combustion processes have a higher perception of high risk in their application. Chemical processes are those that have a long period of return on investment due to the time it takes chemicals to react with the fluids present in the reservoir, whereas the access of carbon dioxide $\left(\mathrm{CO}_{2}\right)$ to the miscible gas recovery processes is an economic challenge related to its acquisition [36].

\section{EOR Planning Strategy}

Successful EOR project implementation requires good and effective planning on the selection of the appropriate technique for the field or 
reservoir under investigation [16,37]. This process involves the integration of a set of parameters governing the technical and economic performance of a reservoir $[8,10,37]$ but not limited to the environmental, commercial, political and governmental factors $[37,38,39,40]$. Careful attention and step by step implementation of these parameters greatly improve the possibility of a successful EOR project. Several problems that may be encountered during EOR project implementation can be identified and avoided with efficient early screening studies ${ }^{[16]}$

The planning stage seeks to answer the following: (1) the volume of oil remaining after secondary recovery, (2) the location of resources or reserves, (3) and the reasons why these reserves were not recovered, (4) fields with the greatest pressure and production decline after secondary recovery and what are the causes of this decline [16].

The structure of the different stages of the project, the objectives, descriptions, human resources, necessary equipment, institutions and costs will be established during the planning stage. Partnerships with some internal and external institutions for advanced oil recovery activities in Angola as well as monitoring and sequestration of $\mathrm{CO}_{2}$ produced in advanced oil recovery activities will be established. The EOR project implementation involves three main stages [16,17,41]: (1) EOR project selection, (2) project implementation and optimization, (3) field abandonment as shown in Fig. 6.

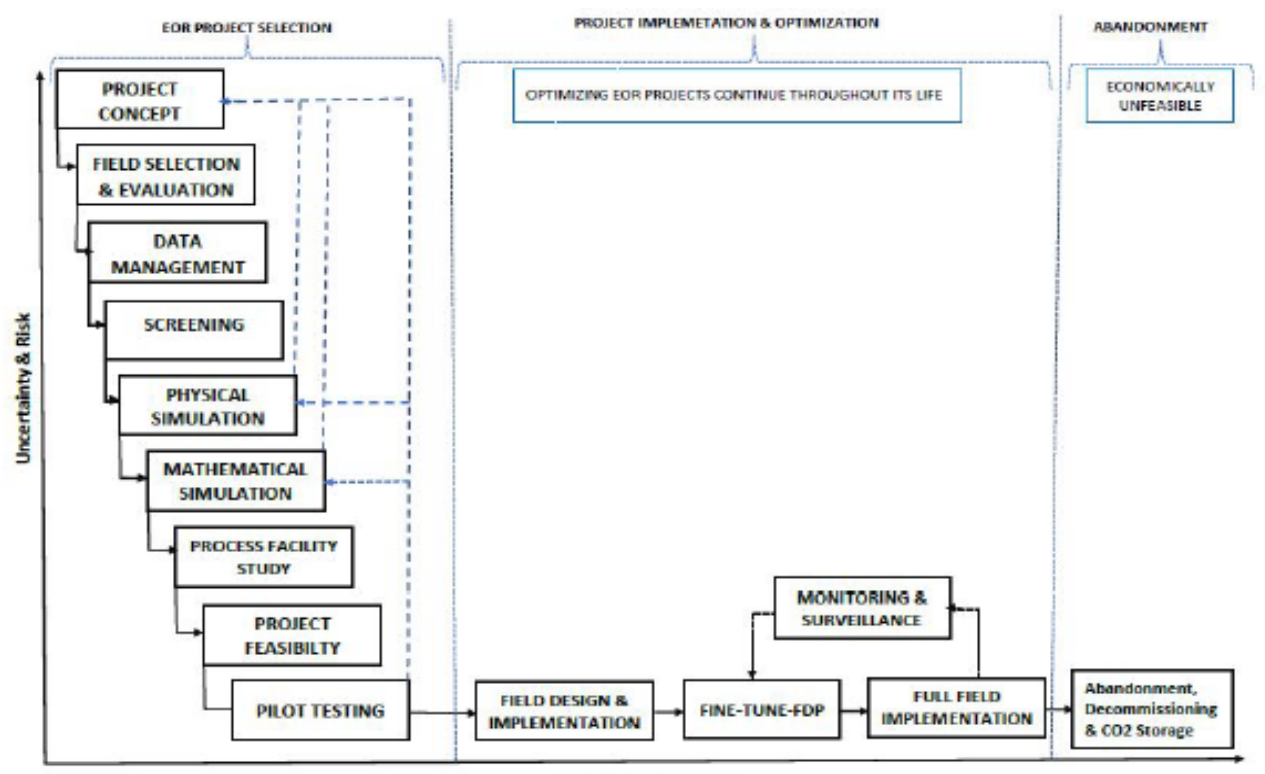

Effort \& Investment

Figure 6: Effective EOR planning strategy. Adapted from ${ }^{[16,17,41]}$.

\subsection{EOR Project Selection}

This is the stage of selecting the appropriate EOR technique and verify whether it is economically feasible. This consists of data management, field evaluation, screening of EOR method, physical and mathematical simulation studies, process facility study, then project feasibility where the environment and full-scale economic evaluation are included. If the project is categorized feasible, then the pilot test design and implementation are needed ${ }^{[41]}$.

\subsubsection{Concept}

This is the stage of the EOR project where the ideas are developed The EOR project concept is presented to the top managers to justify the initiation of the project with outlines of the background, context and need for the project, the project's objectives, expected results and resources required. All the project initiation documents needed to start up a project will be provided including templates for project proposal, business case, feasibility study, project scope definition, human resources, staff recruitment and creating a project office.

\subsubsection{Field selection and evaluation}

The main objective of this phase of the project is in the selection of potential fields for the implementation. These include (1) fields with pressure and production decline after secondary recovery, but with potential reserves remaining, (2) use the results of geological analysis and dynamic modelling or some other production reports to identify the potential fields of EOR implementation, (3) fields with heavy oil that was not possible to produce under conventional production methods. The identification of these fields will help in predicting the volume of activities that can be undertaken during the different phases of the project.

4.1.3. Data Management
Data management is stage is dedicated to data collection, analysis and integration from potential fields for EOR application in Angola, including fields around the world where these techniques have been successfully applied. Data from successful EOR projects all over the world; which was used as the basis for screening and the determination of the suitability of the investigated EOR technique will be included. The data from successful EOR field projects are obtained from EOR survey reports published biannually in the Oil and Gas Journal [6,42]. This data comprises of three (3) categories: data derived from laboratory studies, data generated from the simulation of oil reservoirs under EOR processes mostly by using commercial reservoir simulation software, and data from successful worldwide projects $[6,39,43,44]$. Data from successful worldwide projects are the most reliable category by the fact that technical and economical capabilities are proved practically ${ }^{[6,39]}$.

The data to be collected and analysed consists of reservoir rock and fluid properties: reservoir depth, oil API gravity, oil viscosity, rock porosity, rock permeability, oil saturation, net pay thickness, reservoir temperature, reservoir pressure, formation water salinity, lithology and hydrocarbon composition. Additional information as remaining reserves, well location and conditions, well spacing, chemicals and oil price, reservoir geometry, and production performance drive mechanism are important for good process selection.

The success of the screening or any other simulation lies in the quantity and quality of data set available or collected. This plays a major role on establishing the screening criteria result on investigated EOR technique [45,46], minimise the deviations between the actual and predicted outputs, as well as checking the performance of the model during testing process ${ }^{[6,39]}$. 
During data analysis, problems that can affect the quality of the data set are identified [8,47], the relationship for the different parameters are analysed $[8,39,45,46]$ and the distribution of the reservoir rock-fluid properties for each EOR method is performed [6]. These include missing data, duplicate data and inconsistent data [6]. A good performance of the data analysis is very important to avoid misleading results ${ }^{[47]}$.

Data processing is crucial to ascertain the quality of the data and identify those that may have a negative or positive impact on the result of the investigation. Then it is cleaned to remove the identified data that can have a negative effect on the efficiency and accuracy of the results. An example of these includes: removing the unsuccessful EOR projects and the inconsistent data for both EOR projects and oilfield data under investigation ${ }^{[43,45,46,47]}$.

Inconsistent data is defined in this context as data containing both discrepancies and impossible values ${ }^{[45]}$. This may result from fields where oil saturation at the end (current) is greater than the oil saturation at the start of the production, which seems to be impossible for field oil production. The consistency of the oil gravity and viscosity data can also be analysed. This will avoid having oilfield data with high oil gravity and high oil viscosity simultaneously as both parameters are indirectly proportional [6].

\subsubsection{EOR Screening Process}

The screening process is related to technical EOR process selection. This is the stage of technical selection of suitable EOR technique for each specific field that aims to improve sweeping or displacement efficiency (Figure 3). The screening process is used to reduce uncertainties in assessing the applicability of EOR. The identification of a targeted volume of hydrocarbons not accessible by primary or secondary recovery methods is useful information for the success of screening process which depends on each type of EOR process in answering the questions listed in Table $4^{[16]}$.

Table 4: Required answers to the identification of a target volume of not accessible by conventional methods ${ }^{[16]}$

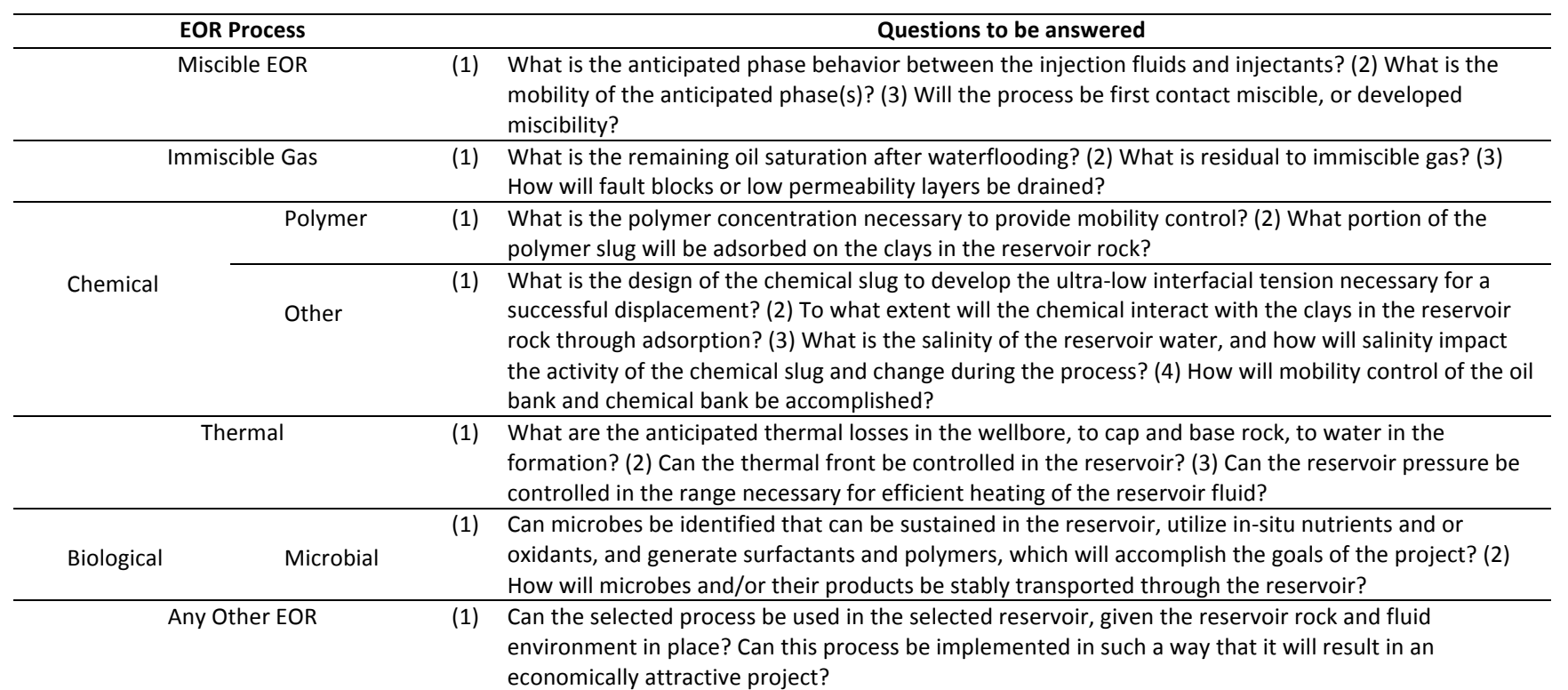

Three methods can be used to select the appropriate techniques for oil recovery: conventional methods, geological methods, and advanced methods.

- Conventional selection is applied by using the selection options in commercial analytical tools to expand the assessment and validation of the applicability of the most viable recovery process to the field under assessment ${ }^{[21]}$. Tables, graphs (box plots histograms, scatter plots, or a combination of these) are derived by combining data on the properties of fluids and rocks from the fields under investigation and data from the fields where these methods have been successfully applied are utilised in the selection process. Data from successfully implemented EOR projects worldwide, are published by the Society of Petroleum Engineers (SPE) and Oil \& Gas Journal and can be used to assess the project's compatibility for a respective method or technique to be implemented. This data will be used to establish or define the compatibility range for advanced recovery techniques for the fields under investigation. There are also commercial software on the market such as PRIze (heavy oil), Sword (light oil), or others $^{[21]}$. Table 5 illustrates data published by Adasani and Bai[43].

- Geological method (Study): Knowledge of the geology of the reservoir is critical to the success of the EOR project ${ }^{[16]}$. The geological characteristics of the database of an EOR project which has been successfully implemented, will be used to compare with data from the field under investigation. Geological and reservoir analyzis include [16,17,21]: (1) lithology, heterogeneity of the reservoir through petrophysical properties, type of trap, analysis of the reservoir structure, diagenesis, depositional system, geological age, depth, temperature, porous thickness, porosity, permeability, horizontal and vertical continuity reservoir, connectivity through the reservoir, composition of the rock matrix, characterization of oil properties, distribution of oil saturation, etc; (2) revisiting all logs, core samples, fluid data and results of geological models that allow a satisfactory adjustment of the production performance history; (3) reservoir mineralogy study determining the amount of injectors adsorption which determines the volume of injectors needed for success; (4) estimate resources when direct data are limited or unavailable, reduce potential uncertainties in assessing the applicability of EOR or increase recovery factors in a reservoir under assessment.

- Advance EOR screening method. This is based on data mining and artificial intelligence techniques through simultaneous combinations of more than two reservoir and fluid properties[21]. There are several models of advanced selection methods for advanced oil recovery applying artificial intelligence such as Fuzzy Logic (Fuzzy-Logic), Neural Networks (Neural Network), Neuro-Fuzzy, etc. The data for this method are divided into two groups: training data and validation data. The data is obtained from EOR projects successfully implemented worldwide, in which $80 \%$ of the data is for training and $20 \%$ for validation. These values are randomly selected until the optimized model is identified. The identified model will be used to select the appropriate technique. Once the optimized model is identified, the test phase will be followed using data from the field under investigation. Several studies have been performed using 
Advanced EOR screening methods or artificial intelligence $(\mathrm{AI})^{[8,37,39,48,49,50,51,52,53]}$ with promising results on EOR screening processes.

Table 5: Summary of EOR screening criteria ${ }^{[43]}$.

\begin{tabular}{|c|c|c|c|c|c|c|c|c|c|c|c|}
\hline \multicolumn{5}{|c|}{ Oil properties } & \multicolumn{7}{|c|}{ Reservoir characteristics } \\
\hline SN & EOR method & \# Projects & Gravity ( AFI) & Viscosity (cp) & Porosity $(\mathrm{X})$ & $\begin{array}{l}\text { Oil saturation } \\
(\mathrm{q} \text { PV })\end{array}$ & Formation type & $\begin{array}{l}\text { Permeatility } \\
\text { (md) }\end{array}$ & Net thickness & Depth (it) & Temperature (F) \\
\hline \multicolumn{12}{|c|}{ Miscable gas injection } \\
\hline 1 & $\mathrm{cos}$ & 153 & |22)-45 Avg 37 & $35-0^{3}$ Avg 2.08 & $\begin{array}{l}\text { 3-37 Avg } \\
15.15\end{array}$ & 15-89 Avg. 46 & Sandstone or Carbonate & $\begin{array}{l}1.5-4500 \text { Avg. } \\
209.73\end{array}$ & [Wide Range] & $\begin{array}{l}1500^{b}-13365 \text { Avg } \\
6230.17\end{array}$ & 82-257 Avg. 138.10 \\
\hline 2 & Hydrocarbon & 67 & $\begin{array}{l}{[23] \text {-57 Avg }} \\
38.3\end{array}$ & $\begin{array}{l}18000-0.04 \text { Avg. } \\
286.1\end{array}$ & $\begin{array}{l}4.25-45 \text { Avg. } \\
14.5\end{array}$ & [30] - 98 Avg. 71 & Sandstone or Carbcolate & $\begin{array}{l}0.1-5000 \text { Avg. } \\
726.2\end{array}$ & $\begin{array}{l}\text { [Thin unless } \\
\text { dipping] }\end{array}$ & $\begin{array}{l}4040[4000]-15900 \\
\text { Avg. } 83436.6\end{array}$ & 85-329 Avg. 202.2 \\
\hline 3 & WAG & 3 & 33-39 Ave 35.6 & $0.3-0.9$ Avz 0.6 & $\begin{array}{l}11-24 \mathrm{Avz} \\
18.3\end{array}$ & & Sandstone & $\begin{array}{l}130-1000 \mathrm{AvE} \\
1043.3\end{array}$ & NC & $7545-8887$ AvE 8216.8 & 194-253 Avg. 229.4 \\
\hline 4 & Nitrogen & 3 & $\begin{array}{l}38(35)-54 \text { Avg. } \\
47.6\end{array}$ & $0.2-0$ ' Avg. 0.07 & $\begin{array}{l}7.5-14 \text { Avg. } \\
11,2\end{array}$ & $\begin{array}{l}0.76[0.4]-0.8 \\
\text { Avg, } 0.78\end{array}$ & Sandstone or Carbonate & $\begin{array}{l}0.2-35 \text { Avg } \\
15.0\end{array}$ & $\begin{array}{l}\text { [Thin unless } \\
\text { dipping] }\end{array}$ & $\begin{array}{l}10000[6000)-18500 \\
\text { Avg. 14633.3 }\end{array}$ & 190-325 Avg. 266.6 \\
\hline \multicolumn{12}{|c|}{ Immiscible gas injection } \\
\hline 5 & Nitrogen & 8 & 16-54 Avg, 34.6 & $\begin{array}{l}18000-0^{4} \mathrm{Avg} \\
2256.8\end{array}$ & $\begin{array}{l}11-28 \mathrm{Avg} \\
19.46\end{array}$ & 47-98.5 Avg. 71 & Sandstone & $\begin{array}{l}3-2800 \text { Avg. } \\
1041.7\end{array}$ & & $\begin{array}{l}\text { 1700-18500 Avg. } \\
79142\end{array}$ & 82-325 Avg. 173.1 \\
\hline 6 & $\mathrm{CO} 2$ & 16 & 11-35 Avg, 22.6 & 592-0.6 Avg, 65.5 & $\begin{array}{l}17-32 \text { Avg. } \\
26.3\end{array}$ & 42-78 Avg. 56 & Sandstone or Carbonate & $\begin{array}{l}30-1000 \text { Avg. } \\
217\end{array}$ & & 1150-8500 Avg, 3385 & 82-198 Avg. 124 \\
\hline 7 & Hydrocarbon & 2 & $22-48$ Avg 35 & 4-0.25 Avg 2.1 & $\begin{array}{l}5-22 \mathrm{Avg} \\
13.5\end{array}$ & $75-83$ Avg. 79 & Sandstone & $\begin{array}{l}40-1000 \mathrm{Avg} \\
520\end{array}$ & & $6000-7000$ Avg 6500 & 170-180 Avg. 175 \\
\hline 8 & Hydrocarbon + WAG & 14 & 9.3-41 Avg. 31 & $\begin{array}{l}16000-0.17 \text { Avg. } \\
3948.2\end{array}$ & $\begin{array}{l}18-31.9 \text { Avg. } \\
25.09\end{array}$ & Avg. 88 & Sandstone or Carbonate & $\begin{array}{l}100-6600 \mathrm{AvE} \\
2392\end{array}$ & & $\begin{array}{l}2650-9199 \text { AvZ. } \\
7218.71\end{array}$ & 131-267 Avg. 198.7 \\
\hline \multicolumn{12}{|c|}{ Chermical methods } \\
\hline 9 & Polymer & 53 & 13-42.5 Avg. 26.5 & $\begin{array}{l}4000^{\circ}-0.4^{4} \text { Avg } \\
123.2\end{array}$ & $\begin{array}{l}\text { 10.4-33 Avg. } \\
22.5\end{array}$ & 34-82 Avg. 64 & Saadstone & $\begin{array}{l}1.8^{2}-5500 \mathrm{Avg} . \\
834.1\end{array}$ & {$[\mathrm{NC}]$} & $9460-700$ Avg. 4221.9 & 237.2-74 Avg 167 \\
\hline 10 & $\begin{array}{l}\text { Alkaline surfactant } \\
\text { polymer (ASP) }\end{array}$ & 13 & $\begin{array}{l}23[20]-34[35] \\
\text { Avg. } 32.6\end{array}$ & $\begin{array}{l}6500^{8}-11 \text { Avg. } \\
875.8\end{array}$ & $\begin{array}{l}26-32 \mathrm{Avg} \\
26.6\end{array}$ & $\begin{array}{l}68[35]-74.8 \\
\text { Avg. } 73.7\end{array}$ & Sandstone & $596 \mid 10]-1520$ & {$[\mathrm{NC}]$} & $\begin{array}{l}3900[9000]-2723 \mathrm{Avg} \\
2984.5\end{array}$ & $\begin{array}{l}158|200|-118[80] \\
\text { Avg. 121.6 }\end{array}$ \\
\hline 11 & Surfactant $+\mathrm{P} / \mathrm{A}$ & 4 & 22-39 Avg, 31.75 & 15.6-2.63 Avg. 7.08 & $\begin{array}{l}\text { 14-16.8 Avg. } \\
15.6\end{array}$ & $43.5-53$ Avg 49 & Sandstone & $\begin{array}{l}50-60 \text { Avg. } \\
56.67\end{array}$ & {$[\mathrm{NC}]$} & 5300-625 Avg. 3406.25 & 155-122 Avg. 12633 \\
\hline \multicolumn{12}{|c|}{ Themnat mectianical methods } \\
\hline 12 & Combustion & 27 & $\begin{array}{l}|10|-38 \text { Avg } \\
23.6\end{array}$ & $\begin{array}{l}{[5000 \mid 2770-1.44} \\
\text { Avg. 504.8 }\end{array}$ & $\begin{array}{l}14-35 \text { Avg. } \\
23.3\end{array}$ & [50]-94 Avg. 67 & $\begin{array}{l}\text { Sandstone or Carbonate } \\
\text { [Preferably Carbonate] }\end{array}$ & $\begin{array}{l}10-15000 \text { Avg. } \\
1981.5\end{array}$ & {$[>10]$} & $\begin{array}{l}400-11300(11500) \\
\text { Avg } 55696\end{array}$ & 6A.4-230 Avg 175.5 \\
\hline 13 & Steam & 274 & $\begin{array}{l}{[8]-33 \mathrm{Avg}} \\
14.61\end{array}$ & $\begin{array}{l}\text { SE6- }-3^{\mathrm{h}} \text { Avg } \\
3259496\end{array}$ & $\begin{array}{l}12-65 \text { Avg } \\
32.2\end{array}$ & 35-90 Avg. 66 & Sandstone & $\begin{array}{l}1^{1}-15001 \text { Avg. } \\
2669.70\end{array}$ & {$[>20]$} & 200 -s000 Avg. 1647.42 & 10-350 Avg. 105.91 \\
\hline 14 & Hot water & 10 & $12-25$ Avg. 18.6 & $\begin{array}{l}8000-170 \text { Avg } \\
2002\end{array}$ & $\begin{array}{l}\text { 25-37 Avg. } \\
31.2\end{array}$ & 15-85 Avg. 58.5 & Sandstone & $\begin{array}{l}900-6000 \text { Avg. } \\
3346\end{array}$ & - & 500-2950 Avg. 1942 & 75-135 Avg. 98.5 \\
\hline 15 & [Surfaxe mining] & - & $\mid 7]-\mid 11]$ & [Zero cold Alaw] & {$[\mathrm{NC}]$} & [ $>8$ wt: Sand] & [Mineable tar sand] & {$[\mathrm{NC}]$} & {$[>10]$} & $\begin{array}{l}\text { [P 3:1 overburden to } \\
\text { sand ratiol }\end{array}$ & [NC] \\
\hline \multicolumn{12}{|c|}{ Microbial } \\
\hline 16 & Microbial & 4 & 12-33 Avg, 26.6 & $\begin{array}{l}8900-1.7 \text { Avg } \\
2977.5\end{array}$ & $\begin{array}{l}12-26 \text { Avg. } \\
19\end{array}$ & 55-65 Avg. 60 & Sandstone & $\begin{array}{l}180-200 \mathrm{Avg} \\
190\end{array}$ & - & $1572-3464$ Avg, 2445.3 & 86-90 Avg, 88 \\
\hline
\end{tabular}

\subsubsection{Physical simulation}

Laboratory tests are conducted to verify that on the micro and macro scale, the method works, and to determine the critical physical design parameters of the injected rock/fluids system or the rock's behaviour towards the process used. The micro scale involves specifying the parameters with an impact on displacement efficiency whereas on the macro-scale the parameters that determine optimum sweep efficiency are specified. An example on micro-scale is a determination on Minimum Miscible Pressure and Multiple contacts for miscible processes and adsorption experiments for the rock-slug interaction, phase behaviour and IFT for chemical processes ${ }^{[41]}$.

An example on macro-scale is slug size for chemical processes, water alternating gas (WAG) ratios for miscible displacements, pressure and temperature requirement for thermal processes. The macro scale also includes the field operating parameters such as well placement, pattern determination, injection rates and pressures, and quality control specifications of the projects ${ }^{[41]}$.

Additional laboratory tests consist of (1) rocks / native core; routine core and SCAL, Porosity and permeability, Xray Diffraction (XRD) and Scanning Electron Microscopy (SEM), Energy-dispersive X-ray (EDX) analysis, rocks wettability; (2) water Formation and injection test: $\mathrm{pH}$, salinity, density, viscosity, complete water analysis, bacterial, scaling tendency; (3) oil characteristic: density, viscosity, melting point, acid number, composition, oil type; (4) chemical test: alkaline-surfactantpolymer (ASP) if necessary add co-surfactant and solvent where each can be mixed/formulated ${ }^{[41]}$.

Several laboratory studies ${ }^{[54,55]}$ have been implemented for rock-fluid or fluid-fluid interaction with a purpose to investigate the best EOR scenarios for EOR projects.

\subsubsection{Mathematical simulation}

Simulation models can be implemented to optimize the designed EOR parameters, the net present value and reduce the financial risk of EOR projects. According to Hite et al. ${ }^{[16]}$, modelling EOR projects requires consistency between the parameters used in reservoir simulation and geological model, then validated with Pre-EOR reservoir performance. This requires much more data and time than scale-up techniques and secondary recovery project design studies. Five main steps are required for EOR modelling process ${ }^{[16]}$ : (1) selection of the appropriate reservoir simulator, (2) collecting valid input data, (3) history matching past production-pressure performance of the reservoir, (4) predicting future EOR project performance, (5) determining the optimum EOR project design, by conducting sensitivity analysis.

Anriansyah ${ }^{[41]}$ in his presentation summarizes the hard work that can be performed up to history matching for reservoir performance determination. The sensitivity studies are crucial for designing and optimizing the technical EOR projects where project facility studies, as well as economic and environmental studies (project feasibility), are conducted for decision making. The input data for EOR reservoir simulation consist of: (1) static 3D reservoir geology model (porosity, facies, permeability distribution), (2) dynamic reservoir data (SCAL Special core analysis, PVT - pressure, volume, temperature and production data with pressure), (3) laboratory study as EOR type e.g. ASP. Anriansyah ${ }^{[41]}$ describes the complete process for physical and mathematical simulation up to history matching for reserves estimation, production performance and proposing best production scenario.

\subsubsection{Project facility studies}

The main EOR project facility studies are injection facility and production facility studies ${ }^{[41]}$ : (1) production facilities: Production test collector station, should be separated from the existing facility, to ensure measurements are more accurate and make handling easier particularly with respect to emulsions, (2) injection facilities studies: water treatment to fulfil the criteria and compatibility with reservoir. The process is also performed through filtering, free oil and plug from a microbe, water softener, neutral $\mathrm{pH}$. Hence, the water composition must be adjusted to the condition from a laboratory test and the chemical retains its properties as formulated. The injection facility necessary for each EOR project are (1) chemical method (ASP), the 
facility consists of a tank(for chemical) - mixer tanks (one for main solvent and another for solvents as formulated in the laboratory), filter, storage tank/ surge tank, transfer pump and pipe between equipment, injection pump to the well, (2) gas/ solvent method - the facility consists of separator (for absorption, distillation, gas dryer etc.), surge tank, pipe for the surface facility to wellhead and compressors (transfer and injection.), (3) thermal method - the facility consists of heat exchanger and boiler, water treatment, pipe (with insulation for steam transport) and pump, (4) microbe method - the facility consist of mixer tank (nutrition), pipes, transfer and injection pumps.

\subsubsection{Project feasibility}

The feasibility study is performed to determine the overall project suitability and result that can be used as guidance during pilot implementation. The study consists of determining (1) quantity and quality water injection data and water process required, (2) quantity quality, and operational condition of EOR media that is needed (such chemical material: interfacial tension, concentration etc.), (3) the best pattern locations including area and pattern type that is recommended (4) surface facility that needed, (5) oil and gas reserves on pilot scale and full-field scale, and finally (6) forecast production for pilot-scale ${ }^{[41]}$.

\subsubsection{Pilot testing}

The pilot test should be designed to provide the quantitative information needed to calibrate models to predict commercial performance and to reduce the project risk to an acceptable level ${ }^{[16]}$ and ensure the efficiency of the selected EOR method in the field ${ }^{[56]}$. Nevertheless, there are some uncertainties in the critical parameters for the project's viability that cannot be resolved in the laboratory or through modelling. In some EOR projects, the pilot tests are not necessary and the modern simulation methods are enough once the reservoir geology is understood and there is sufficient analogue experience $^{[16]}$.

Hence, the pilot testing objectives include also the following assessment of the EOR process for full-field implementation ${ }^{[17,57]}$ : (1) evaluate recovery efficiency, (2) assess effects of reservoir geology on performance, (3) reduce technical and economic issues in production forecasts, (4) obtain data to calibrate reservoir-simulation models, (5) identify operational issues and concerns, (6) assess the effect of development options on recovery, (7) assess environmental impact, (8) evaluate operating strategy to improve economics and recovery.

EOR pilot test range from single-well tests (with injection only or including production) to single-pattern or multipattern pilots ${ }^{[17]}$. There are some additional tests that may be needed: pre-and post-test cores; logging and sampling observation wells and other data gathering methods ${ }^{[16]}$. The pilot test is designed and conducted as a small-scale project ${ }^{[56]}$. Hence, dedicated and appropriate personnel, facilities, and wells are required, along with a commitment to use the resources to design, implement and carry the pilot to its conclusion ${ }^{[16]}$. The Pilot EOR execution comprises Monitoring and surveillance program and quality assurance (QA)/quality control (QC) procedures ${ }^{[16,41]}$.

The design parameters (surface and subsurface) with the pilot response results are monitored, studied, analysed and interpreted. The final design and results obtained from the pilot test are very useful for finetuning of the reservoir simulation model ${ }^{[56]}$. The Monitoring and surveillance program consists of (1) monitoring production wells (daily production test - gross/net, weekly wellhead pressure, dynamic fluid level, monthly static bottom hole pressure); (2) monitoring injection well (daily-rate injection, injectant concentration, bottom hole pressure, weekly well head pressure, oxygen activate logging twice in the pilot, fall off test as necessary); (3) monitoring EOR plant (chemical/ polymer/ miscible and immiscible gas etc.); (4) surveillance program (tracer test, pulse test, pressure build-up, and skin factor minimum twice in the pilot test. pattern balancing, fluid drift, pattern realignment for gaining comprehensive data in building confident level from field trial/ pilot result) ${ }^{[16,41]}$

\subsection{EOR Project implementation and optimization}

Based on the result of EOR feasibility studies, the Field Development Planning (FDP) is designed and implemented ${ }^{[41]}$ in order to maximize the ultimate recovery in a practical timeframe ${ }^{[56]}$. The FDP also includes activity steps that are necessary such as regulator guidance, budget and subsurface and surface preparation. Furthermore, procurement to monitor the EOR full field implementation, the Engineering, Procurement, Construction and Installation contract as well as production and inaction wells is also necessary. Risk mitigation measures are also needed to avoid any unwanted disturbance or other factors which may delay the project full-field Implementation ${ }^{[16,17,41]}$.

Hence, parameters as (1) location of the existing facilities, (2) capacity and process description of the existing plant, (3) layout of the area to define the accessibility of the future expansion of the existing facilities, (4) existing pipeline i.e. size, length, maximum and minimum flow rate, battery limits, lifetime, turn down ratio of the existing pipeline, (5) the existing utilities: the source of the power generation and the maximum production power, (6) the available capacities of the existing storage tank are considered during the design process ${ }^{[56]}$.

Prior to project start-up, field personnel must be trained because an EOR project does not represent" business as usual" in the oilfield ${ }^{[16]}$ as well as in Angola where EOR projects are considered to be new. The EOR project development planning and management should include both the project expectation, data gathering, quality assurance (QA), quality control ( $Q C)$, monitoring and surveillance activities to be carried out during the life of the project ${ }^{[16,41]}$.

The recommended surveillance for EOR project implementation may include pressure or temperature data in observation wells, production fluid samples, quality control activities on the injection fluid facilities, as well as the normal field operations activities ${ }^{[16]}$. The QA and QC activities include material bulk volume calculation as requested, then sampling randomly, after which laboratory tests are conducted to know the quality as well as specification ${ }^{[41]}$. The monitoring plan are similarly monitored in pilot testing implementation or monitoring the production wells, injection wells and EOR plant. Some of the available new surveillance methods and tools that can be used are continuous downhole pressure, temperature and flow rate measurements, cross-well tomography and 4-D seismic tools ${ }^{[27]}$. Some technical issues and limitations of EOR methods are summarized in Tables 2, 3, and 4, respectively.

\subsection{EOR Project abandonment}

Field abandonment is performed after all economic possibilities have been exhausted. The economic life of a project usually ends when the net cash flow becomes permanently negative, which will be accompanied by the deactivation of the field as well as $\mathrm{CO}_{2}$ sequestration and storage where feasible. Consequently, the economic viability of the field, quality and control is performed. In the case of the project not being economically feasible, then (1) create conditions for field abandonment, (2) identify teams specialized in $\mathrm{CO}_{2}$ sequestration and storage, (3) create conditions for the storage of $\mathrm{CO}_{2}$ for use in any subsequent EOR projects.

\section{Conclusions}

The general strategic plan for EOR projects design steps in Angola oilfields has been presented and proposed in this paper. Once these techniques have been applied, it can provide a significant increase in oil recovery as well as extend the life cycle of the reservoirs. The success of an EOR implementation requires effective planning on the selection of the appropriate technique for the field or reservoir under investigation. This includes good data quality and quantity, good screening process, project design and understating of critical reservoir parameters and uncertainties. Angola National EOR Work Team (ANEWT) within the National Agency for Oil, Gas and Biofuels (ANPG) must be set up to coordinate the Angolan Oil industry and government attempts to design and develop the EOR program together with operators and service companies to ensure that overall hydrocarbons recovery is maximized. Field and other key personnel must be trained, specialized and the executor team involved in this project must be supported from top management in operational decision making and independent in the handling area. Applying tax and contractual incentives whenever necessary and cooperation with operators, service companies, universities, research and technological innovation centres can result in mutually beneficial relationships and developments in the sector. 


\section{Acknowledgement}

We thank Sonangol EP for permission to prepare and publish this paper.

\section{Conflict of interest}

The authors declare that there is no conflict of interest regarding the publication of this manuscript.

\section{References}

[1] ISCO, T. (2007). Enhanced oil recovery (eor). A Teledyne Technologies Company.

[2] Al-Anazi, B. D. (2007). Enhanced oil recovery techniques and nitrogen injection. CSEG Recorder, pages $29-33$.

[3] Aladasani, A. (2012). Updated EOR screening criteria and modeling the impacts of water salinity changes on oil recovery. Missouri University of Science and Technology.

[4] Akanji, L. (2014). From primary to tertiary recovery mechanisms: an evolution of technologies for ior/eor in hydrocarbon reservoirs. In International workshop on advancements in reservoir petroleum engineering and enhanced oil recovery methods, Baku, Azebaijan.

[5] Lake, L. W. and Walsh, M. P. (2008). Enhanced oil recovery (eor) field data literature search. Technical report, University of Texas at Austin.

[6] Ramos, G. A. R. (2018). Neuro-fuzzy based screening for EOR projects and experimental investigation of identified techniques in oilfield operations. PhD thesis, University of Aberdeen.

[7] McCormack, M. P., Thomas, J. M., Mackie, K., et al. (2014). Maximising enhanced oil recovery opportunities in ukcs through collaboration. In Abu Dhabi International Petroleum Exhibition and Conference. Society of Petroleum Engineers.

[8] Ramos, G. A. and Akanji, L. (2017c). Data analysis and neuro-fuzzy technique for eor screening: Application in angolan oilfields. Energies, 10(7):837.

[9] Ramos, G. and Akanji, L. (2017a). Technical screening of enhanced oil recovery methods-a case study of block $c$ in offshore angolan oilfields. In First EAGE/ASGA Petroleum Exploration Workshop, pages $c p-531$. European Association of Geoscientists \& Engineers.

[10] Ramos, G. A. and Akanji, L. (2017b). Application of artificial intelligence for technical screening of enhanced oil recovery methods. Journal of Oil, Gas and Petrochemical Sciences.

[11] Kokal, S. and Al-Kaabi, A. (2010). Enhanced oil recovery: challenges and opportunities. World Petroleum Council, pages 64-69.

[12] Stosur, G. J. (2003). Eor: Past, present and what the next 25 years may bring. SPE 84864

[13] Hite, G. J. S. J. R., Carnahan, N. F., and Miller, K. (2003). The alphabet soup of ior, eor and aor: Effective comunication requires a definition of terms. SPE 84908.

[14] Romero-Zer'on, L., editor (2012). Introduction to Enhanced Oil Recovery (EOR) Processes and Bioremediation of Oil Contaminated Sites. ISBN 978-953-51-0629-6. InTech, Janeza Trdine 9, 51000 Rijeka, Croatia.

[15] Stosur, G. J., Hite, J. R., Carnahan, N. F., Miller, K.,et al. (2003). The alphabet soup of ior, eor and aor: effective communication requires a definition of terms. In SPE International Improved Oil Recovery Conference in Asia Pacific. Society of Petroleum Engineers.

[16] Hite, J. R., Bondor, P. L., et al. (2004). Planning eor projects. In SPE International Petroleum Conference in Mexico. Society of Petroleum Engineers.

[17] Al-Mjeni, R., Arora, S., Cherukupalli, P., Van Wunnik, J., Edwards, J., Felber, B. J., Gurpinar, O., Hirasaki, G. J., Miller, C. A., Jackson, C., et al. (2010). Has the time come for eor. Oilfield Review, 2011(22):4.

[18] Ahmed, T. and Meehan, N. (2012). Advanced Reservoir Management and Engineering. ISBN: 978-0-1238-5548-0. Gulf Professional Publishing is an imprint of Elsevier, 2nd edition.
[19] Lake, L. W. (1989). Enhanced Oil Recovery. Englewood Clifts,NJ: Prentice-Hall.

[20] Sheng, J. J. (2011). Modern Chemical Enhanced Oil Recovery Theory and Practice. Gulf Profissional Publishing /Elsevier Inc.

[21] Alvarado, V. and Manrique, E. (2010). Enhanced oil recovery: field planning and development strategies. Gulf Professional Publishing.

[22] Wright, D., le Poidevin, S., Morrison, G., and Thomas, R. (1993). Potential from enhanced oil recovery applications in australia. AGSO Journal of Australian Geology and Geophysics, 14(4):343-351.

[23] Marle, C. (1991). Oil Entrapment and Mobilization In Critical Reports on Applied Chemistry Volume 33. Basic Concepts in Enhanced Oil recovery Processes. Elsivier Applied Science.

[24] Chauveteau, G. and Sorbie, K. (1991). Basic concepts in enhanced oil recovery processes. Elsevier Applied Science, London, 33.

[25] Muggeridge, A., Cockin, A., Webb, K., Frampton, H., Collins, I., Moulds, T., and Salino, P. (2013). Recovery rates, enhanced oil recovery and technological limits. Royal Society Publishing.

[26] Smalley, P. C., Ross, A. W., Brown, C., Moulds, T. P., and Smith, M. J. (2009). Reservoir technical limits: a framework for maximizing recovery from oil fields. SPE Reservoir Evaluation \& Engineering, 12(04):610-629.

[27] Muskat, M. (1953). Oil recovery 100 per cent? Industrial \& Engineering Chemistry, 45(7):1401-1405.

[28] Arriola, A., Willhite, G. P., and Green, D. W. (1983). Trapping of oil drops in a noncircular pore throat and mobilization upon contact with a surfactant. Society of Petroleum Engineers Journal, 23(01):99-114.

[29] Buckley, S. E. and Leverett, M. (1942). Mechanism of fluid displacement in sands. Transactions of the AIME, 146(01):107-116.

[30] Fayers, F. J. and Muggeridge, A. H. (1990). Extensions to dietz theory and behavior of gravity tongues in slightly tilted reservoirs. SPE Reservoir Engineering, 5(04):487-494.

[31] Goodlett, G., Honarpour, M., Chung, F., and Sarathi, P. (1986b). The role of screening and laboratory flow studies in eor process evaluation. SPE 15172

[32] Carcoana, A. (1992). Applied Enhanced Oil Recovery. Prentice-Hall, Inc, Englewood Cliffs, New Jersey 07632.

[33] Satter, A., Iqbal, G. M., and Buchwalter, J. L. (2008). Practical Enhanced Reservoir Engineering. Assisted With Simulation Software. PennWell Corporation, Oklahoma, USA, illustrated edition edition.

[34] Chatzis, I., Morrow, N. R., et al. (1984). Correlation of capillary number relationships for sandstone. Society of Petroleum Engineers Journal, 24(05):555-562.

[35] Thomas, S. (2008). Enhanced oil recovery-an overview. Oil \& Gas Science and Technology-Revue de I'IFP, 63(1):9-19.

[36] Bondor, P. (2010). Eor-the time is now: its contribution to world oil supply. SPE Distinguished Lecture Program, Los Angeles.

[37] Ramos, G. A., Elias, B., and Yates, K. (2020b). Screening reservoir candidates for enhanced oil recovery (eor) in angolan offshore projects. Angolan Mineral, Oil \& Gas Journal, 1(1):6-10.

[38] Al-Mutairi, S. M. and Kokal, S. (2011). Eor potential in the middle east: Current and future trends. SPE 143287.

[39] Kamari, A., Nikookar, M., Sahranavard, L., and Mohammadi, A. H. (2014). Efficient screening of enhanced oil recovery methods and predictive economic analysis. Springer, pages 815-824. DOI 10.1007/s00521-014- 1553-9.

[40] Mohan, H., Biglarbigi, K., Carolus, M., and Wagener, D. V. (2011). Assessing the eor potential of the united states. SPE 145073.

[41] Anriansyah, A. (2017). Eor (enhance oil recovery): Feasibilityimplementation-evaluation.

[42] Koottungal, L. (2014). Worlwide eor survey. Oil \& Gas.

[43] Adasani, A. A. and Bai, B. (2011). Analysis of eor projects and updated screening criteria. Journal of Petroleum Science and Engineering, 79(1-2):10-24. 
[44] Zerafat, M., Ayyatollahi, S., Mehranbood, N., and Barzegan, D. (2011). Bayesian network analysis as a tool for efficiency eor screening. SPE 143282.

[45] Saleh, L. D.,Wei, M., and Bai, B. (2014). Data analysis and update screening criteria for polymer flooding based on oilfield data. SPE 168220.

[46] Chauhan, P. D. (2014). Data analysis and summary for surfactantpolymer flooding based on oil field projects and laboratory data. Master's thesis.

[47] Nageh, M., Ela, M. A. E., Tayeb, E. S. E., and Sayyouh., H. (2015). Application of using fuzzy logic as an artificial intelligence technique in the screening criteria of the eor technologies. SPE-175883-MS.

[48] Akanji, L. and Sandrea, R. (2016). A neuro-fuzzy approach to screening reservoir candidate for eor. Advances in Petroleum Exploration and Development. 12(1): 1-14. DOI:10.3968/8743.

[49] Chung, T.-H., Carrol, H. B., and Lindsey, R. (1995). Application of fuzzy expert system for eor project risk analysis. SPE 30741, pages 411-418.

[50] Dickson, J. L., Leahy-Dios, A., and Wylie, P. L. (2010). Development of improved hydrocarbon recovery screening methodologies. SPE 129768.
[51] Gharbi, R. B. (2000). An expert system for selecting and designing fEORg processes. Journal of Petroleum Science and Engineering, 27(1-2):33-47.

[52] Guerillot, D. (1988). Eor screening with an expert system. In Petroleum Computer Conference. Society of Petroleum Engineers.

[53] Zhou, C. D., Wu, X.-L., and Cheng, J.-A. (1993). Determining reservoir properties in reservoir studies using a fuzzy neural network. SPE 26430. SPE Annual Technical Conference and Exhibition, Houston, USA, 3-6 October.

[54] Goodlett, G., Honarpour, M., Chung, F., and Sarathi, P. (1986a). The role of screening and laboratory flow studies in eor process evaluation. In SPE Rocky Mountain Regional Meeting. Society of Petroleum Engineers.

[55] Ramos, G. A., Akanji, L. T., and Afzal, W. (2020a). A novel surfactant-polymer/alkaline-surfactant-polymer formulation for enhanced oil recovery (eor) processes. Energy \& Fuels.

[56] El Ela, M. A., Sayyouh, H., et al. (2014). An integrated approach for the application of the enhanced oil recovery projects. Journal of Petroleum Science Research, 3(4):176-188.

[57] Teletzke, G. F., Wattenbarger, R. C., Wilkinson, J. R., et al. (2010). Enhanced oil recovery pilot testing bestpractices. SPE Reservoir Evaluation \& Engineering, 13(01):143-154. 